Reprod. Nutr. Dévelop., 1987, 27 (1 A), 13-19.

\title{
Reproductive performance of female goats given progestagen associated with PMSG and/or HMG in deep anestrus
}

\author{
F. CAIROLI (1), C. TAMANINI $\left({ }^{3}, 4\right)$, G. BONO (2), F. CHIESA $\left({ }^{2}\right)$, A. PRANDI $\left({ }^{2}\right)$ \\ (1) Istituto di Ostetricia e Ginecologia Veterinaria, Universita' di Milano, \\ Via Celoria, 10, 20133 Milano, Italy. \\ (2) Istituto di Fisiologia Veterinaria, Universita' di Bologna, \\ Via Belmeloro, 8/2, 40126, Bologna, Italy. \\ ${ }^{3}{ }^{3}$ Istituto di Fisiologia Veterinaria, Universita' di Bari, \\ Via Caduti di Tutte le Guerre, 1, 70126 Bari, Italy.
}

\begin{abstract}
Summary. During deep anestrus and after a 21-day fluorogestone acetate (FGA) treatment, 200 pluriparous lactating Alpine goats were given randomly one of four treatments: (A) $500 \mathrm{IU}$ of pregnant mare serum gonadotropin (PMSG) $48 \mathrm{~h}$ before sponge removal ; (B) $500 \mathrm{IU}$ of PMSG $48 \mathrm{~h}$ before sponge removal and an ampoule of human menopausal gonadotropin (HMG) at sponge removal; (C) two ampoules of HMG at sponge removal; (D) four ampoules of HMG at sponge removal. All the goats were mated naturally during estrus. The percentage of goats kidding (fertility rate) was $6,34,40$ and $36 \%$ for groups $A, B, C$, and D, respectively; the number of kids/pregnant female (prolificacy) averaged between 1.33 and 1.72. The accuracy of pregnancy diagnosis on the basis of plasma progesterone concentration 20 to 22 days after mating was not particularly satisfactory, mainly because many pregnant goats, and especially group A goats, showed abnormally prolonged luteal activity. The determination of total estrone 60 days after mating gave almost $100 \%$ overall accuracy.
\end{abstract}

\section{Introduction.}

Cycling female goats given progesterone or progestagen associated with adequate doses of pregnant mare serum gonadotropin (PMSG) and/or human chorionic gonadotropin (HCG) for 20 to 21 days present a satisfactory fertility rate (Dhindsa, Hoversland and Metcalfe, 1971 ; Minotakis et al., 1972 ; Corteel, 1975 ; Corteel, Gonzales and Nunes, 1982). These treatments are less effective if carried out during the pre-breeding or anestrous season (Corteel, Gonzales and Nunes, 1982). In a previous work (Tamanini et al., 1985), we observed that an estrus similar in its behavioural and endocrinological aspects to that under natural conditions could be induced in anestrous goats treated with progestagen associated with PMSG, but that PMSG alone was inadequate to ensure satisfactory estrus synchronization.

On the contrary, the administration of human menopausal gonadotropin (HMG) ensured good estrus synchronization, as reflected by plasma luteinizing hormone (LH) profiles (Tamanini et al., 1985) ; this was due to the short half-life of HMG as compared with PMSG (Schams et al., 1978; Lauria et al., 1982).

(4) Correspondence and reprint requests. 
Treatment with HMG could therefore be an alternate way of inducing ovulation in female goats.

The reproductive performance observed in pluriparous (but not immature) anestrous goats treated with either PMSG and HMG or HMG alone was fairly satisfactory (Tamanini et al., 1984) ; these data however were not meaningful due to the small number of animals used.

The present experiment was undertaken to investigate the effects of HMG administered alone or in association with PMSG after fluorogestone acetate (FGA) treatment on the fertility and prolificacy of female goats in deep anestrus.

\section{Material and methods.}

Animals and treatments. - The experiment began in April. At that period, goats in Northern Italy $\left(45^{\circ} \mathrm{N}\right.$ Latitude) are in deep anestrus. Two hundred Alpine females and 20 bucks were maintained outdoors on a diet of hay and concentrate. All the females had been pregnant during the preceding breeding season and kidded between January and February ( 2 to 3 months before the beginning of the experiment) and were milked twice daily.

Females. - After insertion of a vaginal sponge ( $45 \mathrm{mg}$ of FGA), left in place for 21 days, the females were randomly treated intramuscularly as follows : (1) $500 \mathrm{IU}$ of PMSG $48 \mathrm{~h}$ before sponge removal (group $A, n=50$ ) ; (2) $500 \mathrm{IU}$ of PMSG $48 \mathrm{~h}$ before sponge removal and an ampoule of HMG equivalent to $75 \mathrm{IU}$ of $\mathrm{LH}$-like + $75 \mathrm{IU}$ of follicle-stimulating hormone (FSH)-like activity at sponge removal (group $B, n=50)$; (3) two ampoules of HMG (150 IU of LH-like + $150 \mathrm{IU}$ of FSH-like activity) at sponge removal (group $C, n=50$ ), and (4) four ampoules of HMG (300 IU of LH-like $+300 \mathrm{IU}$ of FSH-like activity) at sponge removal.

Bucks. - The fertility of the 20 bucks used had been confirmed by the pregnancy of females served during the preceding season. According to Roberts (1971), they were given i.m. $1000 \mathrm{IU}$ of PMSG $+25 \mathrm{mg}$ of testosterone every 3 days for 21 days because sequential administration of gonadotropins has been proved to be satisfactory in restoring breeding activity and body odor during the non-breeding season (Masaki and Masuda, 1968).

On the basis of endocrine patterns of induced estrus (Tamanini et al., 1985), each buck was put with 10 females $30 \mathrm{~h}$ after sponge removal and left there for $72 \mathrm{~h}$; those females that had mated at least twice were separated from the bucks until all the others had mated. All the females were then put again with the bucks.

Twenty days after sponge withdrawal, the males were again put with the females and left there for one week.

Blood collection. - Blood samples were collected from each female in heparinized tubes by jugular venipuncture once weekly, beginning 4 weeks before sponge insertion and until sponge removal and twice weekly until 60 days after mating. The blood was centrifuged at $2300 \times \mathrm{g}$ for $10 \mathrm{~min}$ and the plasma thus obtained was stored at $-20^{\circ} \mathrm{C}$ until assay. 
Hormone assay. - Plasma progesterone and total estrone concentrations were determined as described by Bono et al., (1983) and Tamanini et al. (1986), respectively. For total estrone determination, $10 \mu \mathrm{l}$ of unextracted plasma were assayed using antiestrone serum diluted $1: 5000$; its cross-reactions $(\%)$ were : estrone 100 , estrone glucuronate 60 , estrone sulphate 20 , estradiol $17 \alpha$ and $17 \beta 1$ and estrial $<0.01$. All the plasma samples were analyzed for progesterone; on the contrary, only those collected 60 days after mating were analyzed for total estrone because only females which were at least 55 days pregnant had plasma total estrone concentrations significantly higher than non-pregnant animals. In a previous work, Tamanini et al. (1986) showed that plasma total estrone levels higher than 0.42 $\mathrm{ng} / \mathrm{ml}$ indicated pregnancy; this concentration was at least 3 standard deviations (SD) above the mean total estrone values observed in non-pregnant goats.

\section{Results.}

Plasma progesterone concentrations never exceeded $0.4 \mathrm{ng} / \mathrm{ml}$ in any of the goats until sponge removal, suggesting that they were acyclic.

Behavioral estrus. - All the goats exhibited behavioral estrus beginning 24 to $36 \mathrm{~h}$ after sponge removal, irrespective of the treatment ; estrus length ( 30 to $34 \mathrm{~h}$ ) was very similar to that observed during the spontaneous estrous cycle (Bono et al., 1983). All the goats were mated, but no matings were observed when the bucks, still showing libido, were introduced 20 days after sponge removal.

Reproductive findings. - Table 1 shows fertility, prolificacy, the accuracy (\%) of pregnancy diagnosis estimated by plasma progesterone levels 20 to 22 days after

TABLE 1

Accuracy (\%) of pregnancy diagnosis by plasma progesterone and total estrone determinations, fertility rate and prolificacy observed in 200 pluriparous goats after different gonadotropins were administered during the anestrous season. Pregnancy was diagnosed on the basis of plasma progesterone level and total estrone concentrations 20 to 22 and 60 days after insemination, respectively.

\begin{tabular}{|c|c|c|c|c|}
\hline & $\begin{array}{c}\text { PMSG } \\
(n=50\rangle\end{array}$ & $\begin{array}{c}\text { PMSG + HMG } \\
(n=50)\end{array}$ & $\begin{array}{l}\mathrm{HMG} \times 2 \\
(\mathrm{n}=50)\end{array}$ & $\begin{array}{l}\mathrm{HMG} \times 4 \\
(\mathrm{n}=50)\end{array}$ \\
\hline \multicolumn{5}{|l|}{ Progesterone (a) } \\
\hline & 16.6 & 65.3 & 64.5 & 64.2 \\
\hline $\begin{array}{l}\text { of negative diagnosis (\%) } \\
\text { Overall accuracy }(\%)\end{array}$ & $\begin{array}{l}100 \\
70.0\end{array}$ & $\begin{array}{l}100 \\
82.0\end{array}$ & $\begin{array}{l}100 \\
78.0\end{array}$ & $\begin{array}{l}100 \\
80.0\end{array}$ \\
\hline \multicolumn{5}{|l|}{ Total estrone (b) } \\
\hline $\begin{array}{l}\text { of positive diagnosis }(\%) \\
\text { Accuracy }\end{array}$ & 60.0 & 85.0 & 100 & 100 \\
\hline of negative diagnosis $(\%)$ & 100 & 100 & 100 & 100 \\
\hline Overall accuracy $(\%)$ & 96.0 & 94.0 & 100 & 100 \\
\hline Kiddings (fertility rate) & $3(6 \%)$ & $17(34 \%)$ & $20(40 \%)$ & $18(36 \%)$ \\
\hline $\begin{array}{l}\text { Prolificacy } \\
\text { (kids/pregnant female) }\end{array}$ & 1.33 & 1.52 & 1.40 & 1.72 \\
\hline
\end{tabular}

(a) Plasma progesterone levels higher than $1 \mathrm{ng} / \mathrm{ml}$ were considered as indicative of pregnancy.

(b) $0.42 \mathrm{ng} / \mathrm{ml}$ is the minimal level for diagnosing a goat as pregnant. 
mating, and the accuracy (\%) of pregnancy diagnosis by total estrone determination 60 days after insemination.

Gestation length averaged 148 to 153 days.

Fertility rate was highest $(40 \%)$ in HMG $\times 2$-treated goats, though the rates in PMSG + HMG and HMG x 4-treated ones were slightly lower. On the contrary, fertility induced by PMSG alone was very low $(6 \%)$.

The groups did not differ significantly as to prolificacy. In almost all goats, except for 2, 1 and 2 animals in groups $A, B$ and $C$ respectively, plasma progesterone levels were high ( $>1 \mathrm{ng} / \mathrm{ml}$ ) 3 to 6 days after mating, and in pregnant females they remained high until the end of the experiment. In most of the nonpregnant animals, plasma progesterone levels decreased to undetectable values 20 to 22 days after mating but some goats $(15,9,11,10$ in groups $A, B, C$ and $D$, respectively) continued to show high progesterone levels until 45 to 50 days after mating (fig. 1); the plasma progesterone levels in these goats were significantly lower $(P<0.01)$ than in pregnant goats only 40 days after mating. No further increase of this steroid was ever observed after the progesterone concentrations had dropped.

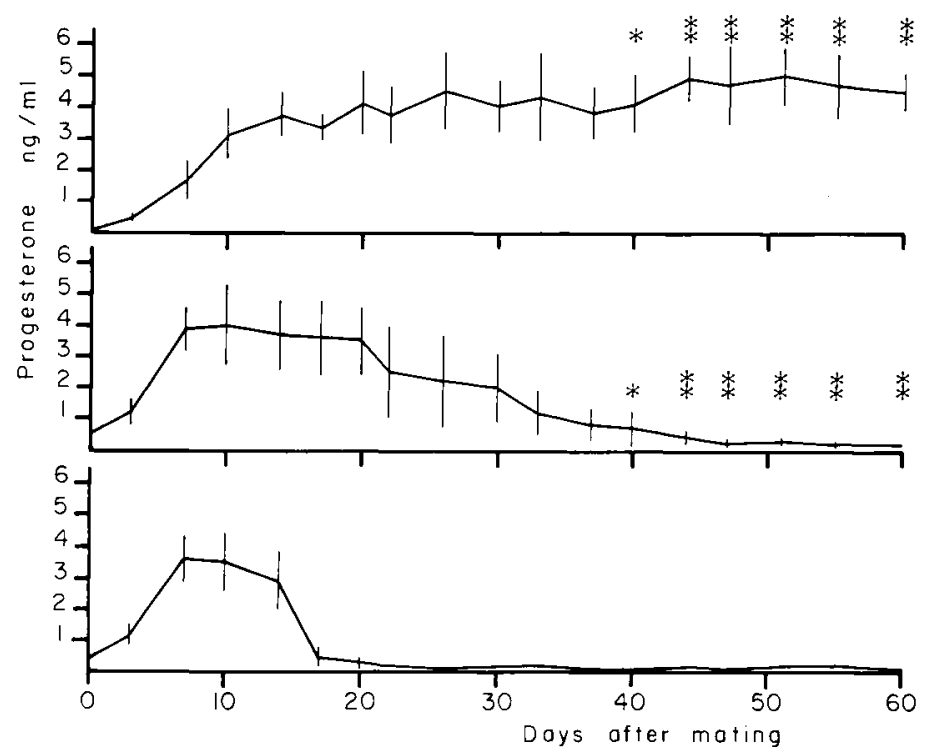

FIG. 1. - Plasma progesterone concentration $(\bar{X} \pm S E)$ in female goats during the first 60 days after mating. Upper panel : pregnant goats $(n=58)$; central panel : non-pregnant goats with abnormally prolonged luteal activity $(n=45)$; lower panel : non-pregnant goats with normal luteal activity ( $\mathrm{n}=92$ ).

${ }^{*}$ and ${ }^{*}$ in the upper and central panels, indicate significantly different plasma progesterone levels in pregnant $v s$ non-pregnant goats $(P<0.01$ and $P<0.001$, respectively).

Irrespective of the treatment, all the females subsequently kidding showed high total estrone concentrations (> $0.42 \mathrm{ng} / \mathrm{ml}$ ) 60 days after mating; although 2 $(4 \%)$ and $3(6 \%)$ goats in groups $A$ and $B$, respectively, showed high total estrone levels, they did not kid. No goats kidded that showed plasma total estrone levels $<0.4 \mathrm{ng} / \mathrm{ml} 60$ days after mating. 


\section{Discussion.}

PMSG administered to female goats in deep anestrus after a 21-day FGA treatment was effective in inducing behavioral estrus, while FGA alone was unsuccessful (Tamanini et al., 1985). However, fertility was not satisfactory with PMSG : only three out of fifty goats kidded (even if almost all ovulated, as shown by the progesterone profile after induced estrus). These data disagree with those of Corteel, Gonzales and Nunes (1982) and Corteel et al. (1984) who obtained higher fertility rates after FGA-PMSG treatment of anestrous goats. There are two possible reasons for this discrepancy. The first is the period when the experiments were carried out. Corteel et al. (1984) do not mention the month the treatment began ; treatment is more successful as the breeding season approaches (in our experiment, the goats were in deep anestrus). Secondly, the short interval between kidding and onset of treatment ( 2 to 3 months) may have caused a further reduction in the fertility rate; Corteel (1975) observed a satisfactory fertility rate only when the treatment started more than 4 months after kidding.

Further ovarian stimulation with HMG after PMSG administration (group B) or the administration of two different doses of HMG alone (groups $C$ and D) was effective in inducing a significant increase in the fertility rate, though this rate was lower than the rate observed by others (Corteel, Gonzales and Nunes, 1982) during the anestrous season.

The prolonged luteal activity observed in several goats after induced estrus might have been due to early embryonic death, which would account for the high percentage of false positive pregnancy diagnosis obtained by progesterone assay; nevertheless, the negative diagnosis was $100 \%$ accurate. Except for group A goats, the percentage of non-pregnant females with high plasma progesterone levels 20 to 22 days after mating gave an overall accuracy similar to that reported by Thimonier et al. (1977), Chiesa et al. (1981) and Corteel et al. (1984). We cannot explain the high percentage of non-pregnant animals in group A that were diagnosed as pregnant and can only hypothesize that, because of its long half-life (Lauria et al., 1982), PMSG induced a prolonged stimulation of the ovaries (Tamanini et al., 1985), which possibly resulted in excessive luteinization. Plasma progesterone determination 20 to 22 days after mating is therefore not reliable as a pronostication of kidding, even if the negative diagnosis is always correct. In fact, the twice weekly bleeding schedule adopted shows that plasma progesterone concentrations did not decline to those of non-pregnancy for almost 48 days in females that had elevated concentrations at 20 to 22 days but did not subsequently kid.

Pregnancy diagnosis, on the basis of plasma total estrone concentrations (whose high levels are indicative of fetal viability), seems to be much more accurate, even if carried out later than that based on progesterone determination. Thimonier et al. (1977) also tried to determine the number of fetuses by measuring estrogen levels, but the accuracy of the method was unsatisfactory. Those authors, furthermore, analyzed unconjugated estrogens and therefore it is difficult to compare their results with ours. The fact that $\mathbf{5}$ goats did not kid after 
being diagnosed as pregnant may be explained by abortion; however, no symptoms of abortion were found, possibly because the animals were reared outdoors.

Irrespective of the treatment, none of the non-pregnant goats in our study showed behavioral estrus or conceived when males were introduced 20 to 22 days after induced estrus; this suggests non-return to estrus. Also, the plasma progesterone profiles demonstrate that luteal activity (either normal or prolonged), following induced estrus, is never followed by another increase in plasma progesterone concentrations.

In conclusion, it can be assumed after a 21-day FGA treatment, that : (1) PMSG alone cannot induce a satisfactory fertility rate in goats in deep anestrus : (2) HMG, when associated or not with PMSG, markedly increases fertility rate, which however remains unsatisfactory ; (3) non-pregnant goats often show abnormally prolonged luteal activity following induced estrus, and (4) cyclicity is not resumed in non-pregnant goats and they return to anestrus.

Reçu en mai 1986.

Accepté en octobre 1986.

Acknowledgements. - This work was supported by a special grant « Incremento Produttivita Risorse Agricole », subproject $N^{\circ} 1$, paper $N^{0} 36$. Thanks are due to Mr. S. Strada for skilled technical assistance.

Résumé. Performances reproductrices des chèvres traitées à l'aide de progestagènes associés à PMSG et/ou HMG pendant l'anoestrus saisonnier.

Pendant l'anoestrus saisonnier, 200 chèvres alpines multipares en lactation reçoivent une éponge intravaginale imprégnée de $45 \mathrm{mg}$ d'acétate de fluorogestone (FGA) pendant une période de 21 jours. Elles sont réparties en 4 groupes $A, B, C, D$, qui diffèrent par le moment de l'administration, la nature et la dose de gonadotropines : 500 UI de PMSG (A et B), $48 \mathrm{~h}$ avant le retrait de l'éponge vaginale plus (B) 1 ampoule de HMG (75 UI LH + 75 UI FSH) lors du retrait de l'éponge ; 2 ampoules (C) et 4 ampoules (D) de HMG lors du retrait de l'éponge. Toutes les chèvres sont venues en oestrus et ont été inséminées naturellement. La fertilité et la prolificité sont respectivement de 6 et 1,33\% (A), 34 et $1,52 \%$ (B), 40 et $1,40 \%$ (C), 36 et $1,72 \%$ (D). La valeur du diagnostic de gestation par mesure du niveau de progestérone plasmatique 20-22 jours après insémination est limitée, de nombreuses chèvres ne mettant pas bas, ayant une activité lutéale prolongée. En revanche, le diagnostic de gestation par estimation du niveau plasmatique de l'oestrone, 60 jours post-insémination, se montre pratiquement sans défaillance.

\section{Références}

CHIESA F., CRESPI A., GAIANI R., GALEATI G., 1981. Possibilitá di diagnosi precoce di gravidanza nella capra mediante la determinazione del progesterone nel plasma. Atti Societa' Italiana Patologia Allevamento Ovini Caprini. Alghero, 4, 128-136.

CORTEEL J. M., 1975. The use of progestagens to control the oestrous cycle of the dairy goat. Ann. Biol. anim. Bioch. Biophys., 15, 353-363.

CORTEEL J. M., GONZALES C., NUNES J. F., 1982. Research and Development in the control of reproduction. Proc. third int. Conf. Goat Production and Disease. Tucson, Arizona, U.S.A. 584-601. 
CORTEEL J. M., BARIL G., LEBOEUF B., BOUE P., 1984. A comparison of two hormonal treatments to provoke oestrus and ovulation in the anestrous dairy goat. $X^{\text {th }}$ int. Congr. anim. Reprod. artif. Insemin., Urbana-Champaign, 3, 313.

DHINDSA D. S., HOVERSLAND A. S., METCALFE J., 1971. Reproductive performance in goats treated with progestogen impregnated sponges and gonadotrophins. J. anim. Sci, 32, 301305.

LAURIA A., GENAZZANI A. R., OLIVA O., INAUDI P., CREMONESI F., MONITTOLA C., AURELI G., 1982. Clinical and endocrinological investigations on superovulation induced in heifers by human menopausal gonadotropin. J. Reprod. Fert., 66, 219-225.

MASAKI J., MASUDA H., 1968. Seasonal variation in glycerophosphorylcholine content and related characteristics of goats semen. VI int. Congr. anim. Reprod. artif. Insemin., Paris, 1, 301-303.

MINOTAKIS C. S., XENOULIS P. S., KOURAS A., SAMARA D., 1972. The use of MAP impregnated pessaries in stall led goats and the effect of low PMSG dosage. VIth Int. Congr. anim. Reprod. Artif. Insemin., Munich, 2, 1005-1008.

ROBERTS S. J., 1971. Veterinary obstetrics and genital diseases. (Theriogenology) Ithaca N.Y. Edwards Brothers Eds., Ann. Harbor. Michigan.

SCHAMS D., MENZER C. H., SCHALLEMBERGER E., HOFFMANN B., HAHN J., HAHN R., 1978. Some studies on pregnant mare serum gonadotrophin (PMSG) and endocrine responses after application for superovulation in cattle, 122-143. In J. M. SREENAN, Control of reproduction in the cow. M. NIJHOFF, The Hague.

TAMANINI C., CAIROLI F., BONO G., GAIANI R., 1984. Reproductive findings in pluriparous and immature goats induced to ovulate in anestrous season. $X^{\text {th }}$ Int. Congr. anim. Reprod. artif. Insemin., Urbana-Champaign, 3, 351.

TAMANINI C., BONO G., CAIROLI F., CHIESA F., 1985. Endocrine responses induced in anestrous goats by the administration of different hormones after a fluorogestone acetate treatment. Anim. Reprod. Sci, 9, 357-364.

TAMANINI C., CHIESA F., PRANDI A., GALEATI G., 1986. Estrone and estrone conjugate plasma levels throughout pregnancy in the goat : their determination as a pregnancy diagnosis test. Anim. Reprod. Sci., 11, 35-42.

THIMONIER J., BOSC M., DJIANE J., MARTAL J., TERQUI M., 1977. Hormonal diagnosis of pregnancy and number of fetuses in sheep and goats. In Management of reproduction in sheep and goats. Univ. Wisconsin, Madison, Wisconsin, 79-88. 